\title{
Commentary: Robotic lobectomy: Changing times, unchanging principles
}

\author{
Richard S. Lazzaro, MD, FACS, ${ }^{\mathrm{a}, \mathrm{b}}$ and \\ Matthew L. Inra, MD ${ }^{\mathrm{a}, \mathrm{b}}$
}

Evarts Graham performed the first successful pneumonectomy for lung cancer on April 5, 1933, establishing pneumonectomy as the operative treatment of choice for the management of lung cancer at that time. ${ }^{1,2}$ In 1942, Kent and Blades from the Chest Service of the Barnes hospital published their clinical experience of the technique of individual ligation for 27 patients undergoing pulmonary lobectomy, which had previously been read at the 24th Annual Meeting of the American Association for Thoracic Surgery in Toronto. ${ }^{3,4}$ Core principles of preoperative bronchoscopy and operative ligation of the artery followed by ligation of the vein and then bronchus were established. ${ }^{3,4}$ Several decades later, in 1962, Shimkin and colleagues compared case series of pneumonectomy and lobectomy performed by Dr Overholt and Dr Ochsne and demonstrated that "survival after lobectomy was equivalent to pneumonectomy with fewer complications." ${ }^{, 5}$ CALGB 39802 established the feasibility of a standardized approach to video-assisted thoracoscopic surgery lobectomy while preserving core principles of individual ligation technique for the lobectomy with standard node sampling or dissection. ${ }^{7}$ Cerfolio and colleagues ${ }^{8}$ performed a multi-institutional retrospective review of a consecutive series of 1339 patients from 4 institutions, which demonstrated "an impressive stage-

\footnotetext{
From the ${ }^{\mathrm{a}}$ Department of Cardiovascular and Thoracic Surgery, Northwell Health Lenox Hill Hospital, New York; and ${ }^{\mathrm{b}}$ Donald and Barbara Zucker School of Medicine at Hofstra Northwell, Hempstead, NY.

Disclosures: The authors reported no conflicts of interest.

The Journal policy requires editors and reviewers to disclose conflicts of interest and to decline handling or reviewing manuscripts for which they may have a conflict of interest. The editors and reviewers of this article have no conflicts of interest.

Received for publication July 26, 2021; accepted for publication July 30, 2021; available ahead of print Aug 6, 2021

Address for reprints: Richard S. Lazzaro, MD, FACS, Department of Cardiothoracic Surgery, Lenox Hill Hospital, 130 E 77th St, New York, NY 10075 (E-mail: rlazzaro@northwelli.edu).

JTCVS Techniques 2021;10:481-2

2666-2507

Copyright (C) 2021 The Author(s). Published by Elsevier Inc. on behalf of The American Association for Thoracic Surgery. This is an open access article under the CC BY-NC-ND license (http://creativecommons.org/licenses/by-nc-nd/4.0/). https://doi.org/10.1016/j.xjtc.2021.07.032
}

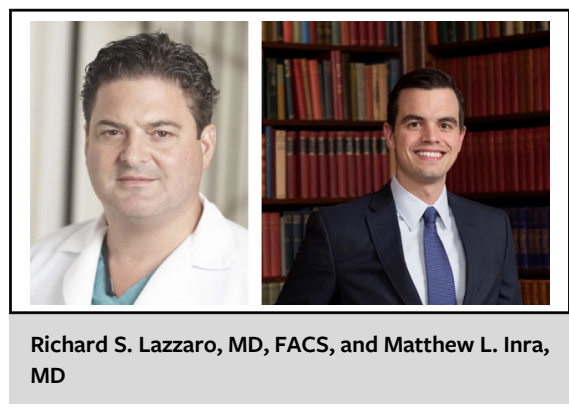

CENTRAL MESSAGE

Surgery will continue to evolve, to change, but the more things change, the more they need to stay the same.

specific survival of patients with completely resected NSCLC."

In this month's issue of JTCVS Techniques, Servais9 ${ }^{9}$ describes a robotic-assisted left lower lobe pulmonary lobectomy in 11 steps. This "how-to" paper provides a safe and reproducible approach for left lower lobectomy that may enhance surgeon adoption, furthering the use of a minimally invasive approach to anatomic pulmonary resection for lung carcinoma. Our group has adopted the robotic-assisted video assisted approach to thoracic surgery with the mandate that surgical principles such as individual ligation technique and optimal nodal evaluation (sampling and/or dissection) be maintained without compromise. Consequently, we concur with Upham and Onaitis, who have stated that "everyone would support less-invasive surgery via any approach if it were able to provide the expected decrease in morbidity and allow for at least equivalent if not improved oncologic outcomes, ${ }^{10}$ and D'Amico, ${ }^{11}$ who has stated that "patients may not be receiving the ideal therapy in the future if surgeons do not recognize and practice the best that surgery has to offer in optimizing oncologic efficacy while minimizing invasiveness and complications." Thoracic surgical treatment for lung cancer has evolved from total organ resection to lobectomy and to anatomic sublobar resection for the appropriate indications and patients. At the current time, the application of a minimally invasive approach to pulmonary lobectomy must maintain the core principles of individual ligation with appropriate nodal evaluation to accomplish a pathologic complete resection. Surgery will continue to evolve, to change, but the more things change, the more they need to stay the same. As Jimmy Carter said, "We must adjust 
to changing times and still hold to unchanging principles." This is also the way.

\section{References}

1. Horn L, Johnson DH, Evarts A. Graham and the first pneumonectomy for lung cancer. J Clin Oncol. 2008;26:3268-75.

2. Graham EA, Singer JJ. Landmark article Oct 28, 1933. Successful removal of an entire lung for carcinoma of the bronchus. By Evarts A. Graham and J. J. Singer. JAMA. 1984:251:257-60.

3. Kent EM, Bladen B. The surgical anatomy of the pulmonary lobes. J Thorac Surg. 1942;12:18-30.

4. Faber LP. Individual ligation technique for lower lobe lobectomy. Ann Thorac Surg. 1990;49:1016-8.

5. Shimkin MB, Connelly RR, Marcus SC, Cutler SJ. Pneumonectomy and lobectomy in bronchogenic carcinoma. A comparison of end results of the Overholt and Ochsner clinics. J Thorac Cardiovasc Surg. 1962;44:503-19.
6. Abbas AE. Surgical management of lung cancer: history, evolution, and modern advances. Curr Oncol Rep. 2018;20:98.

7. Swanson SJ, Herndon JE 2nd, D'Amico TA, Demmy TL, McKenna RJ Jr, Green MR, et al. Video-assisted thoracic surgery lobectomy: report of CALGB 39802 - a prospective, multi-institution feasibility study. J Clin Oncol. 2007; 25:4993-7.

8. Cerfolio RJ, Ghanim AF, Dylewski M, Veronesi G, Spaggiari L, Park BJ. The long-term survival of robotic lobectomy for non-small cell lung cancer: a multi-institutional study. J Thorac Cardiovasc Surg. 2018;155: $778-86$.

9. Servais E. Robotic-assisted left lower-lobe pulmonary lobectomy: eleven steps. J Thorac Cardiovasc Surg Tech. 2021;10:473-9.

10. Upham TC, Onaitis MW. Video-assisted thoracoscopic surgery versus robotassisted thoracoscopic surgery versus thoracotomy for early-stage lung cancer. J Thorac Cardiovasc Surg. 2018;156:365-8.

11. D'Amico TA. The best that surgery has to offer. J Thorac Cardiovasc Surg. 2013; 145:699-701. 